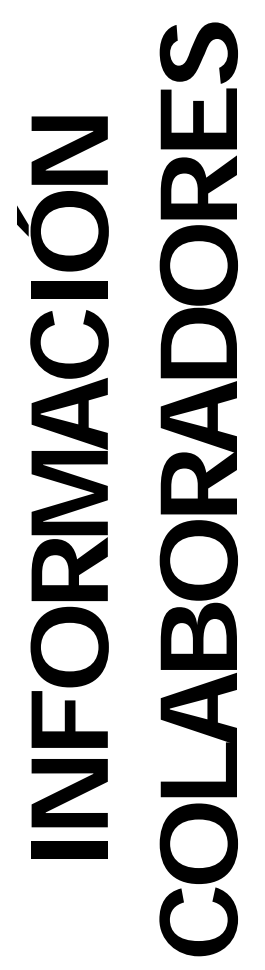




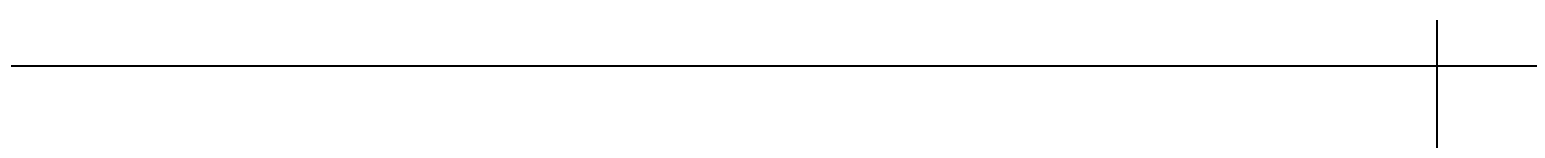




\section{INFORMACIÓN COLABORADORES}

\section{AUTORES}

\section{Alvori Ahlert}

Universidade Estadual do Oeste do Paraná - Brasil

Pós- Doutorando em Educação

E- mail: alvoriahlert@yahoo.com.br

Adrián Cammarota

Universidad Nacional General - Argentina

Doctorando en Ciencias Sociales

E-mail: adriancammarota2000@yahoo.com.ar

Moyra Castro Paredes

Universidad de Talca-Chile

Doctora en Educación

E-mail:mocastro@utalca.cl

Jesús García Mínguez

Universidad de Granada - España

Doctor en Filosofía y Ciencias de la Educación

E-mail: jminguez@ugr.es

Javier Nicolás González Camargo

Universidad Sergio Arboleda- Colombia

Licenciado en Filosofía y Humanidades

Liliana Beatriz Irizar

Universidad Sergio Arboleda- Colombia

Doctora en Filosofía

E-mail: liliana.irizar@gmail.com

María Isabel Lafuente Guantes

Universidad de León - España

Doctora en Filosofía y Letras

E-mail:milafg@unileon.es

Manuel Martín Rodríguez.

Universidad de Granada - España

Doctor en Ciencias Económicas

E-mail:mmartinr@ugr.es 


\section{Camilo Noguera Pardo}

Universidad Sergio Arboleda- Colombia

Magíster en Docencia e Investigación

Javier Ocampo López

Universidad Pedagógica y Tecnológica de Colombia

Doctor en Historia

E-mail: javierocampo11@yahoo.es

\section{María Laura Pérez Gras}

Universidad del Salvador, Argentina

Licenciada en Letras

E-mail: lauraperezgras@yahoo.com.ar

TulioAlfonso Ramírez

Universidad Central de Venezuela

Doctor en Educación

E-mail: tuliorc1@gmail.com

Juan Manuel Sánchez Ramos

Aldeas infantiles SOS - España

Doctorando en Educación Social

E- mail: juan.sanchez@ aldeasinfantiles.es

Diana Elvira Soto Arango

Universidad Pedagógica y Tecnológica de Colombia

Doctora en Filosofía y Ciencias de la Educación

E-mail: dianaelvirasoto@gmail.com

Doris Lilia Torres Cruz

Universidad Pedagógica y Tecnológica de Colombia

Doctora en Ciencias de la Educación

E-mail: dorislilia6@yahoo.com

José G. Viloria Asención

Universidad Nacional Experimental Simón Rodríguez

Doctor Ciencias de la Educación

E-mail: viloriajg@gmail.com 


\title{
INFORMACIÓN Y NORMAS PARA AUTORES
}

\author{
NORMAS PARALA PUBLICACIÓN \\ DE ORIGINALES EN \\ "Revista Historia de la Educación \\ Latinoamericana". 2010
}

ISSN: 0122-7238. Indexada en LATINDEX por COLCIENCIAS: 01227238, agosto de 2001 a diciembre de 2009. Categoría B - PUBLINDEX.

\section{Normas para el envío de originales}

1. Los artículos deben ser inéditos. Tendrán una extensión máxima de 20 folios a doble espacio, con un máximo de 70.000 caracteres, incluidos cuadros, gráficos, notas, imágenes relacionadas con el tema, apéndices y bibliografía. La clasificación de los artículos que se presentan en ésta revista son: Científicos; Reflexión y de Revisión. Las reseñas de los libros tendrán un mínimo de dos cuartillas y un máximo de cuatro. Se debe incluir la carátula. Para reseñar revistas, es indispensable que envíen el número que se va a reseñar.

2. Cada trabajo irá precedido de una hoja donde se incluirá el resumen del Currículo Vital del Autor. Se incluye: Nombre, lugar de trabajo, dirección, E-mail, tel, fax; estatus profesional, línea de investigación y publicaciones de los últimos cinco años de Libros y Revistas, las publicaciones deben incluir ISBN ó el ISSN. (Los datos particulares no serán publicados).

3. Las colaboraciones podrán remitirse en cualquiera de las lenguas oficiales de la Revista: español y portugués. Con todo, al comienzo del trabajo se incluirá dos resúmenes máximos de 5 renglones, uno en español, otro en inglés. Asimismo, se indicarán las palabras clave en ambos idiomas (concisas, si puede ser una sola mejor). Además, todo el artículo se enviará en ingles para la versión electrónica en página Web.

4. Solo se aceptarán apéndices documentales muy breves y en casos justificados.

5. Las notas deberán ir numeradas correlativamente, en caracteres arábigos, voladas sobre el texto e insertas a pie de página.

6. Las referencias bibliográficas observarán la siguiente secuencia: 


\section{Para libros}

OCAMPO LÓPEZ, Javier. (2001): Rafael Bernal Jiménez. Sus ideas educativa, sociológicas humanísticas y la escuela nueva en Boyacá. Colección: Pedagogos colombianos y latinoamericanos No. 1. Bogotá, Rudecolombia, Universidad Pedagógica y Tecnológica de Colombia, Plaza y Janés. IIFA.

\section{Capítulos de libros}

SALDAÑA, Juan José. (1995): Ilustración ciencia y técnica en América, en La Ilustración en la América Colonial. Soto Arango, Diana. PUIG-SAMPER, Miguel Ángel y ARBOLEDA, Luís Carlos. Madrid. Consejo Superior de Investigaciones Científicas. Doce Calles. Conciencias, p.106.

\section{Para artículos}

SOTO ARANGO, Diana Elvira. (2005) “Aproximación histórica a la universidad Colombiana", en Revista Historia de la Educación Latinoamericana. No. 7. Tunja, Universidad Pedagógica y Tecnológica de Colombia. RUDECOLOMBIA, pp. 25-62.

Una vez citada, del modo acá descrito, determinada obra, puede emplearse en ulteriores citas de la misma forma abreviada que incluye sólo el apellido del autor, año de publicación y página donde aparece la cita.

7. La Secretaría de la revista acusará recibo de los trabajos en el plazo de diez días a partir de la fecha de recepción. Tras la pertinente evaluación, por dos pares académicos, el Consejo de Redacción comunicará su resolución a los interesados.

8. Los resúmenes en inglés o abstract deben ser presentados con el aval de un centro especializado en la enseñanza del inglés o bien, de un traductor profesional que certifique dicha actividad.

9. Se adjuntará un resumen del currículo del autor o de los autores que consiste sólo en lo siguiente: Nombre, máximo título académico; institución donde trabaja; publicaciones solo de los últimos cinco años, señalando si es libro o artículo; premios y menciones honoríficas. E-mail.

10. Los autores recibirán pruebas de imprenta para su corrección, debiendo proceder a la misma en un plazo máximo de quince días. Los autores enviarán vía Internet su artículo. Si es relacionado harán entrega del Copyright de Artículo a la Revista.

11. Los autores recibirán dos ejemplares de la revista.

12. Se publicarán recensiones de aquellos libros que lleguen como donación. 


\title{
REQUISITOS DE EDICIÓN
}

Dentro de este orden, a fin de facilitar las tareas de edición/impresión, se encarece la observación de las siguientes pautas:

1. Los trabajos se enviarán vía correo electrónico: rhela@ rudecolombia.edu.co

2. Se utilizará como fuente Timen New Roman, tamaño 12 puntos, pudiendo variar este patrón en función de los distintos niveles jerárquicos del texto.

3. No se recomienda el empleo de símbolos o signos procedentes de fuentes de origen alfabético cirílico, griego y en general, las de procedencia oriental. En caso de necesidad, los textos de esa naturaleza deberán de ser procesados como imágenes. Para destacar palabras o textos se usará exclusivamente cursiva, no negrilla ni subrayado.

4. En caso de remisión se imágenes, deberán incrustarse, no vincularse, en el documento. A este respecto, se recomiendan el empleo del formato JPEG, la inserción en blanco y negro y su preferente agrupación en las páginas finales. Siempre que sea posible, los archivos que contengan imágenes usadas en el documento se entregarán junto con el mismo.

\section{INFORMATION AND REGULATIONS FOR AUTHORS}

\section{REGULATIONS FOR THE PUBLICATION OF ORIGINAL WORKS IN THE ISSUE}

"Revista Historia de la Educación Latinoamericana" 2010

\author{
ISSN: 0122-7238. Indexed In LATINDEX by COLCIENCIAS: 01227238, \\ August 2001 to december 2009. B Category. PUBLINDEX.
}

\section{Regulations for submitting the original works}

1. The articles must be unpublished. They will have a Maxim extension of 20 folios to double-spaced, with a maximum of 70,000 characters, including pictures, graphs, notes, images related to the subject, appendices and bibliography. The articles classification is are: Scientific, Reflexion and Revision. Books review will have a minimum of two pages and a maximum of four. The title page is due to include. In order to review magazines, it is indispensable to send the number that is going to be reviewed. 
2. Each work must be sent with a letter that includes the summary of the Author's Curriculum Vitae. It must include: Name, work place, address, email, telephone number, fax, professional status, research line and publications of books and magazines throughout the last five years. The publications must include ISBN or the ISSN. (The particular data will not be published).

3. The papers will be sent in any of the official languages of the Issue: Spanish and Portuguese. The article must contain two summaries of maximum 5 lines must be included at the beginning, one in Spanish, another in English. Also, the key words in both languages might be included (The fewer words the better). In addition, all the article will be sent in English for the electronic version in the Web page.

4. Documentary appendices will only be accepted provided they are very brief and necessary.

5. The notes will have to be co-relatively numbered, in Arabic characters, placed on the text and inserted as foot page.

6. The bibliographical references will contain the following sequence:

\section{For Books}

OCAMPO LÓPEZ, Javier. (2001): Rafael Bernal Jiménez. Sus ideas educativa, sociológicas humanísticas y la escuela nueva en Boyacá. Colección: Pedagogos colombianos y latinoamericanos No. 1. Bogotá, Rudecolombia, Universidad Pedagógica y Tecnológica de Colombia, Plaza y Janés. IIFA.

\section{Chapters of Books}

SALDAÑA, Juan José. (1995): Ilustración ciencia y técnica en América, en $L a$ Ilustración en la América Colonial. Soto Arango, Diana. PUIG-SAMPER, Miguel Ángel y ARBOLEDA, Luís Carlos. Madrid. Consejo Superior de Investigaciones Científicas. Doce Calles. Conciencias, p.106.

\section{For Articles}

SOTO ARANGO, Diana Elvira. (2005) "Aproximación histórica a la universidad Colombiana", en Revista Historia de la Educación Latinoamericana. No. 7. Tunja, Universidad Pedagógica y Tecnológica de Colombia. RUDECOLOMBIA, pp. 25-62.

Once the article is quoted, in the way described here, it can be used in later cites in the same brief form that includes only the last name of the author, year of publication and page where the quote appears. The article will be placed at the end.

7. The Secretary of the issue will confirm the reception of the articles in the term of ten 
days from the date of reception. After the pertinent evaluation done by two academic peers, the Editorial Committee will communicate their approval to the interested ones.

8. A summary of the author's CV must include: Name, highest degree, work place, publications from the last five years only, indicating if it is a book or an article, awards and honors and E-mail.

9. The authors will receive drafts of the press for their correction, having had to come to the same one in a maximum term of fifteen days. The authors will send via Internet their article. If it is to be published, the authors must deliver the Copyright of the Article to the Issue.

10. The authors will receive two printed versions of the issue.

11. Reviews of those books submitted as donation will be published.

\section{Edition Requirements}

\section{In order to facilitate the edition/printing activities, it is necessary to keep in mind the following guidelines:}

1. The paper must be sent via e-mail: rhela@ rudecolombia.edu.co

2. The font will have to be Times New Roman, size 12 points, which may vary according to the different hierarchic levels in the text.

3. The use of symbols or signs from sources of alphabetical origin such as Cyrillic, Greek, and in general, those of Eastern origin is not advised. In case of necessity, these kind of texts will be processed as images. In order to enhance words or texts, Italics, neither bold type nor underlining will be used exclusively.

4. In the case of sending images, they will have to be incrusted, not linked, in the document. To this respect, it is recommended the use of format JPEG, the insertion in black and white colors and its grouping in the final pages. Whenever possible, the archives that contain images used in the document must be sent along with it. 


\title{
INFORMAÇÃO E NORMAS PARA AUTORES
}

\author{
NORMAS PARA PUBLICAÇÃO \\ DE ORIGINAIS NA
}

"Revista Historia de la Educación Latinoamericana" 2010

ISSN: 0122-7238. Indexada na LATINDEX por COLCIENCIAS: 01227238, Agosto de 2001 a diciembre de 2009. Categoria B - PUBLINDEX.

\section{Normas para envio de originais}

1. Os artigos devem ser inéditos. Deverão ter uma extensão máxima de 20 páginas, com espaço duplo e no máximo 70.000 caracteres, incluindo quadros, gráficos, notas, imagens relacionadas com o tema, apêndices e bibliografia. A classificação dos artigos que se apresentam nesta revista

são: Científicos; de Reflexão e de Revisão. As resenhas dos livros deverão ter no mínimo uma página e no máximo duas. A capa do livro deverá ser incluída. Para resenhas de revistas é indispensável que se envie o número analisado.

2. Cada trabalho será precedido de uma folha na qual se incluirá o resumo do Curriculum Vitae do Autor. Este deverá conter: Nome, lugar de trabalho, endereço, e-mail, telefone, fax, status profissional, linha de pesquisa e publicações dos últimos cinco anos de Livros e Revistas; as publicações devem incluir ISBN ou ISSN. (Os dados particulares não serão publicados).

3. As colaborações poderão ser remitidas em qualquer das línguas oficiais da Revista: espanhol e português. Contudo, no começo do trabalho se incluirá dois resumos com o máximo de 5 linhas, sendo um em espanhol e o outro em inglês. Da mesma forma, devem ser indicadas as palavras-chave em ambos os idiomas (devem ser poucas, se possível uma só). Além disso, o artigo todo será enviado em inglês para a versão eletrônica na página Web.

4. Somente serão aceitos apêndices documentais breves e em casos justificados.

5. As notas deverão estar numeradas correlativamente, em números arábicos, destacados sobre o texto e inseridas ao pé da página.

6. As referências bibliográficas observarão a seguinte sequência: 


\section{Para livros}

OCAMPO LÓPEZ, Javier. (2001): Rafael Bernal Jiménez. Sus ideas educativa, sociológicas humanísticas y la escuela nueva en Boyacá. Colección: Pedagogos colombianos y latinoamericanos No. 1. Bogotá, Rudecolombia, Universidad Pedagógica y Tecnológica de Colombia, Plaza y Janés. IIFA.

\section{Capítulos de livros}

SALDAÑA, Juan José. (1995): Ilustración ciencia y técnica en América, en La Ilustración en la América Colonial. Soto Arango, Diana. PUIG-SAMPER, Miguel Ángel y ARBOLEDA, Luís Carlos. Madrid. Consejo Superior de Investigaciones Científicas. Doce Calles. Conciencias, p.106.

\section{Para artigos}

SOTOARANGO, Diana Elvira. (2005) “Aproximación histórica a la universidad Colombiana", en Revista Historia de la Educación Latinoamericana. No. 7. Tunja, Universidad Pedagógica y Tecnológica de Colombia. RUDECOLOMBIA, pp. 25-62.

Uma vez citada, do modo acima descrito, determinada obra poderá ser empregada em posteriores citações de forma abreviada que inclua somente o nome do autor, ano de publicação e página em que aparece a citação.

7. A Secretaria da revista informará o recebimento dos trabalhos no prazo de dez dias a partir da data de recepção. Após a pertinente avaliação, por dois pares acadêmicos, o Conselho de Redação comunicará sua resolução aos interessados.

8. Deverá ser incluído um resumo do curriculum do autor ou dos autores que consistirá no seguinte: Nome; máximo título acadêmico; instituição em que trabalha; publicação somente dos últimos cinco anos, assinalando se é livro ou artigo; prêmios e menções honrosas; e-mail.

9. Os autores receberão provas de imprensa para sua análise, devendo proceder a mesma num prazo máximo de cinco dias. Os autores enviarão via Internet seu artigo. Se for aprovado para publicação deverão proceder entrega do Copyright de Artigo à Revista.

10. Os autores receberão dois exemplares da revista.

11. Serão publicadas recensões daqueles livros que chegarem como doação. 


\section{REQUISITOSDE EDIÇÃO}

Dentro desta ordem, a fim de facilitar as tarefas de edição/impressão, se faz necessária a observação das seguintes pautas:

1. Os trabalhos serão enviados por correio eletrônico: rhela@ rudecolombia.edu.co

2. Deverá ser utilizada a fonte Times New Roman, tamanho 12, podendo variar este padrão em função dos diferentes níveis hierárquicos do texto.

3. Não se recomenda o emprego de símbolos ou signos procedentes de fontes de origem alfabética cirílica, grega ou, em geral, as de procedência oriental. Em caso de necessidade, os textos dessa natureza deverão ser processados como imagens. Para destacar palavras ou textos se usará exclusivamente cursiva, evitando-se tanto negrito e quanto sublinhado.

4. Em caso de remissão de imagens, estas deverão estar incrustadas, e não anexadas, no documento. A este respeito, recomenda-se o emprego do formato JPEG, a inserção em branco e negro e, preferencialmente, seu agrupamento nas páginas finais. Sempre que for possível os arquivos que contenham imagens usadas no documento serão entregues junto com o mesmo. 


\section{FORMATOS}

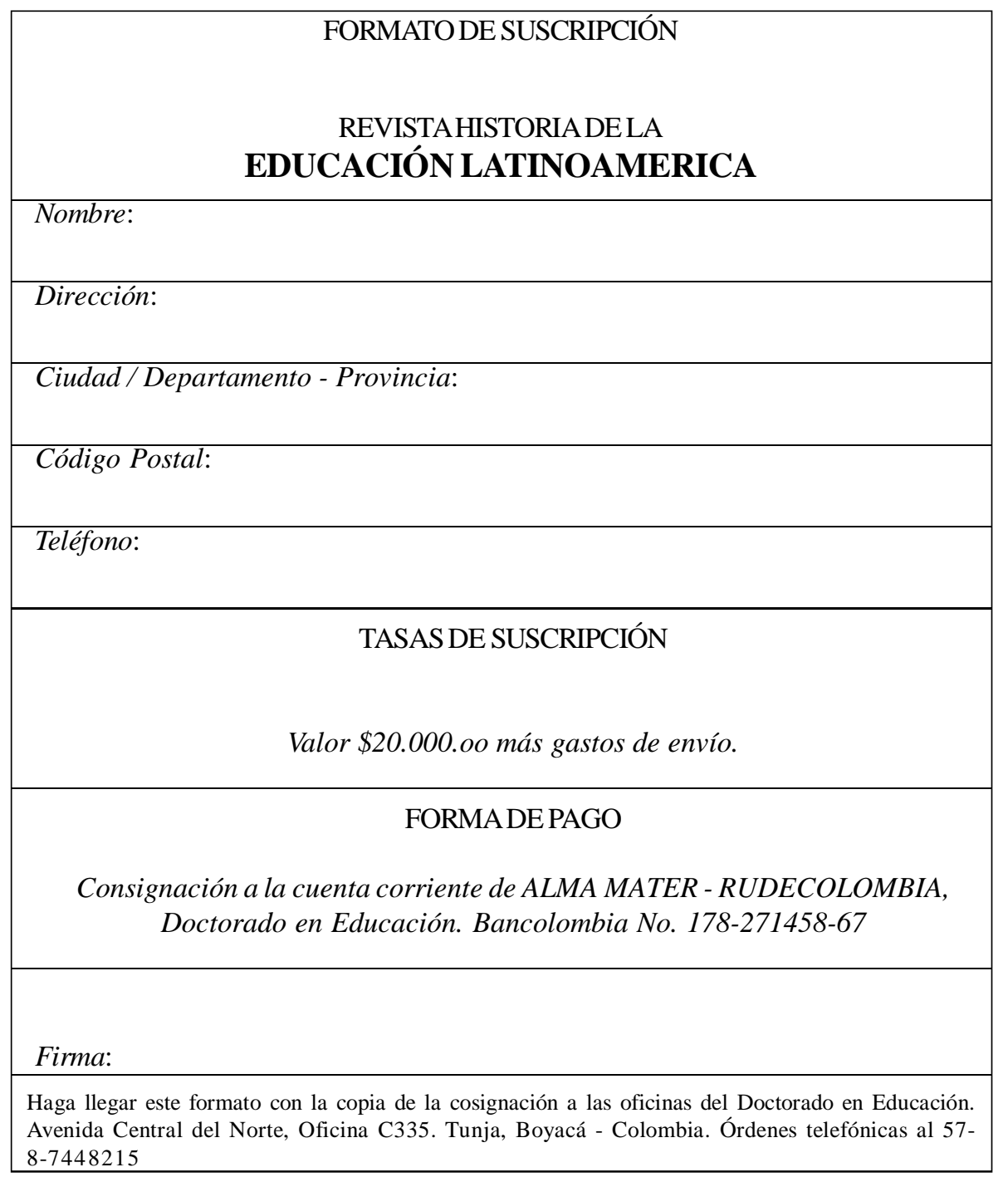

\begin{tabular}{l|l} 
& Rev. hist. edu. latinoam. Vol. 15. Año 2010, pp. $375-384$
\end{tabular}




\begin{tabular}{|c|}
\hline $\begin{array}{c}\text { Copyright } \\
\text { REVISTA HISTORIADE LA } \\
\text { EDUCACIÓN LATINOAMERICA }\end{array}$ \\
\hline Artículo \\
\hline Autor(es) \\
\hline Fecha \\
\hline $\begin{array}{l}\text { Por el presente documento, cedo el Copyright del artículo } \\
\text { arriba indicado para la, Revista } \\
\text { Historia de la Educación Latinoamericana } \\
\text { identificada con ISSN: 0122-7238. }\end{array}$ \\
\hline $\begin{array}{l}\text { El documento se hará efectivo cuando } \\
\text { el trabajo sea aceptado, por el Comité Editorial. }\end{array}$ \\
\hline $\begin{array}{l}\text { Confirmo también que el escrito no contiene materia } \\
\text { cuya publicación viole algún copyright u otro derecho } \\
\text { personal o de propiedad de cualquier persona o entidad. }\end{array}$ \\
\hline Firma: \\
\hline Documento de Identidad: \\
\hline $\begin{array}{c}\text { Nota: el trabajo no será procesado para la publicación hasta que los editores } \\
\text { académicos reciban este impreso diligenciado. }\end{array}$ \\
\hline $\begin{array}{l}\text { Si el artículo no es publicado en la Revista Historia de la Educación } \\
\text { Latinoamericana, este documento no tendrá efecto alguno. }\end{array}$ \\
\hline
\end{tabular}




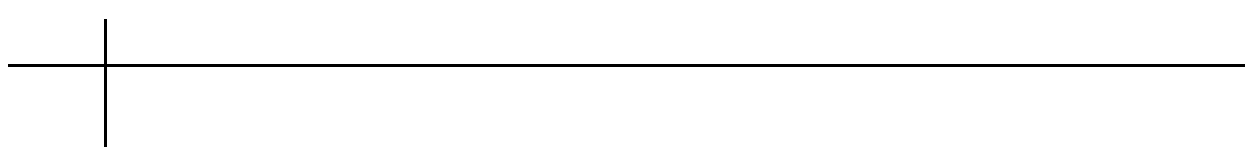


Esta Revista se terminó de imprimir en el

Grupo Imprenta y Publicaciones de la Universidad

Pedagógica y Tecnológica de Colombia, en febrero de 2011

con un edición de 300 ejemplares.

Tunja, Boyacá - Colombia 